\title{
Expression of an Oxalate Decarboxylase Impairs the Necrotic Effect Induced by Nep1-like Protein (NLP) of Moniliophthora perniciosa in Transgenic Tobacco
}

\author{
Leonardo F. da Silva, ${ }^{1}$ Cristiano V. Dias, ${ }^{1}$ Luciana C. Cidade, ${ }^{1}$ Juliano S. Mendes, ${ }^{1}$ Carlos P. Pirovani, ${ }^{1}$ \\ Fátima C. Alvim, ${ }^{1}$ Gonçalo A. G. Pereira, ${ }^{2}$ Francisco J. L. Aragão, ${ }^{3}$ Júlio C. M. Cascardo, ${ }^{1}$ and \\ Marcio G. C. Costa ${ }^{1}$ \\ ${ }^{1}$ Centro de Biotecnologia e Genética, Departamento de Ciências Biológicas, Universidade Estadual de Santa Cruz, Ilhéus, \\ BA 45662-900, Brazil; ${ }^{2}$ Instituto de Biologia, Departamento de Genética e Evolução, Universidade Estadual de Campinas, \\ Campinas, SP 13083-970, Brazil; ${ }^{3} E$ mbrapa Recursos Genéticos e Biotecnologia, Brasília, DF 70770-916, Brazil
}

Submitted 27 December 2010. Accepted 4 March 2011.

Oxalic acid (OA) and Nep1-like proteins (NLP) are recognized as elicitors of programmed cell death (PCD) in plants, which is crucial for the pathogenic success of necrotrophic plant pathogens and involves reactive oxygen species (ROS). To determine the importance of oxalate as a source of ROS for OA- and NLP-induced cell death, a full-length cDNA coding for an oxalate decarboxylase (FvOXDC) from the basidiomycete Flammulina velutipes, which converts $\mathrm{OA}$ into $\mathrm{CO}_{2}$ and formate, was overexpressed in tobacco plants. The transgenic plants contained less $\mathrm{OA}$ and more formic acid compared with the control plants and showed enhanced resistance to cell death induced by exogenous OA and MpNEP2, an NLP of the hemibiotrophic fungus Moniliophthora perniciosa. This resistance was correlated with the inhibition of ROS formation in the transgenic plants inoculated with OA, MpNEP2, or a combination of both PCD elicitors. Taken together, these results have established a pivotal function for oxalate as a source of ROS required for the PCD-inducing activity of OA and NLP. The results also indicate that FvOXDC represents a potentially novel source of resistance against OA- and NLP-producing pathogens such as $M$. perniciosa, the causal agent of witches' broom disease of cacao (Theobroma cacao $\mathbf{L}$.).

Successful colonization of host tissues by necrotrophic plant pathogens requires the induction of plant cell death to provide the nutrients needed for the establishment of pathogenesis (Van Kan 2006). Thus, a main determinant for pathogenicity of these phytopathogens is the production of secreted metabolites and proteins which enable them, ultimately, to kill host tissues (Choquer et al. 2007; Van Kan 2006). Oxalic acid (OA) has long been known to be a pathogenicity determinant of important plant-pathogenic fungi, including several species of Sclerotinia and Botrytis (Van Kan 2006).

Pathogen-produced OA has multiple modes of action that affect the host. OA favors plant cell wall degradation by shifting the apoplastic $\mathrm{pH}$ close to the optimum for cell wall-degrading

Corresponding author: M. G. C. Costa; Fax: +55.73 .3680 .5226 ; E-mail: marciogc.costa@gmail.com

* The $\boldsymbol{e}$-Xtra logo stands for "electronic extra" and indicates that Figures 3,4 , and 6 appear in color online. enzymes and removes the calcium ions that are bound to pectins, leading to a loss of cell wall integrity (Bateman and Beer 1965). OA can also inhibit the plant oxidative burst (Cessna et al. 2000; Guo and Stotz 2007), one of the earliest and most universal plant defense responses against invading microorganisms, probably through $\mathrm{pH}$ changes that occur during the pathogen ingress into host tissues (Kim et al. 2008). The importance of the multifunctional OA is such that Sclerotinia sclerotiorum mutants lacking the ability to produce OA are essentially nonpathogenic, even though they still maintain their full arsenal of cell-wall-degrading enzymes (Godoy et al. 1990). A recent study showed that OA acts as an elicitor of programmed cell death (PCD) in plants and is responsible for the induction of apoptotic-like features in the plant during disease development, in a mechanism that involves the generation of reactive oxygen species (ROS) (Kim et al. 2008). The induction of this fungal-mediated PCD process is required for the pathogenic success of $S$. sclerotiorum.

Another group of PCD elicitors found in many plant pathogens consists of necrosis and ethylene-inducing peptides (NEP) (Pemberton and Salmond 2004). NEP1 was first discovered in Fusarium oxysporum culture filtrates as a $24-\mathrm{kDa}$ protein causing necrosis and induced ethylene production in the coca plant; in addition, NEP1-like proteins (NLP) have been identified in diverse organisms in the past few years, including bacteria, fungi, and oomycetes (Bae et al. 2006; Bailey 1995). Transformation of Colletotrichum coccodes with $F$. oxysporum Nep1 has increased virulence and the spectrum of hosts that could be infected (Amsellem et al. 2002). In Erwinia carotovora, the expression of the Nip gene that encodes an NLP resulted in larger lesions and more rotting of host tissues (Mattinen et al. 2004). In S. sclerotiorum, a reduced or abolished SsNep2 expression correlated with a partial or total, respectively, loss of virulence (Bashi et al. 2010). NLP induce the elevation of internal $\mathrm{Ca}^{2+}$ levels, activation of mitogen-activated protein kinases, formation of ROS, and synthesis of ethylene and pathogenesis-related proteins (Bae et al. 2006; Fellbrich et al. 2002; Jennings et al. 2001; Keates et al. 2003; Qutob et al. 2006; Veit et al. 2001). The cellular process or pathway that is required for the necrosis-inducing activity of NLP remains unknown.

The hemibiotrophic basidiomycete Moniliophthora perniciosa (Stahel) Aime \& Phillips-Mora is the causal agent of witches' broom disease (WBD), one of the most important diseases of cacao (Theobroma cacao L.) in the Americas (Purdy 
and Schmidt 1996). This fungus seems to have originated from the Amazon basin and is known to infect at least five families of dicotyledons, including Malvaceae and Solanaceae (Griffith et al. 2003). Recent evidence has indicated that both OA and NLP are key determinants in $M$. perniciosa pathogenicity. During the progression of the disease, $M$. perniciosa triggers a PCD pathway involving calcium oxalate crystal accumulation and its subsequent degradation into hydrogen peroxide $\left(\mathrm{H}_{2} \mathrm{O}_{2}\right)$ in infected plants, resulting in plant cell death and the generation of a suitable environmental niche for fungal nutrient acquisition and conversion from biotrophic to necrotrophic phase (Ceita et al. 2007). Production of oxalate by mycelia of $M$. perniciosa was recently observed in in vitro studies (Rio et al. 2008), as well as the expression of a gene coding for oxaloacetate acetylhydrolase, which catalyzes the hydrolysis of oxaloacetate to oxalate and acetate in biotrophic-like mycelia. NLP have also been detected in T. cacao tissues infected by $M$. perniciosa (Garcia et al. 2007). The authors have demonstrated that the fungus contains three putative genes encoding NLP, which are apparently located at the same chromosome. MpNEP1 is expressed in the biotrophic and necrotrophic phases, whereas MpNEP2 is only expressed in the biotrophic phase. Both NLP were able to induce necrosis and ethylene emission in tobacco and cacao leaves (Garcia et al. 2007), thus indicating their active involvement in WBD.

Because OA and NLP are elicitors of PCD, which involves ROS (Bae et al. 2006; Fellbrich et al. 2002; Jennings et al. 2001; Kim et al. 2008; Qutob et al. 2006; Schouten et al. 2008), and oxalate can be a potential source of ROS (Shetty et al. 2008), we have tested the hypothesis that oxalate degradation could delay or even inhibit the plant cell death caused by both PCD elicitors. Two major enzymes, oxalate oxidase (OXO) and oxalate decarboxylase (OXDC), are able to degrade OA (Svedruzic et al. 2005). OXO converts OA into $\mathrm{CO}_{2}$ and $\mathrm{H}_{2} \mathrm{O}_{2}$, whereas OXDC promotes the conversion of oxalate into $\mathrm{CO}_{2}$ and formate. To test our hypothesis, we have generated transgenic tobacco plants expressing an OXDC from Flammulina velutipes (FvOXDC) which, in contrast to $\mathrm{OXO}$, does not generate additional $\mathrm{H}_{2} \mathrm{O}_{2}$ (Kesarwani et al. 2000; Walz et al. 2008). Our results showed that FvOXDC was able to confer resistance to both OA and MpNEP2 in all transgenic plants evaluated, which correlated with the inhibition of ROS formation. These results suggest that the induction of PCD by OA and MpNEP2 involves the generation of ROS, which is provided by the conversion of oxalate into $\mathrm{H}_{2} \mathrm{O}_{2}$. Our results also show that $F v O X D C$ may be considered as a potential candidate gene for resistance to OA- and NEP-producing pathogens such as $M$. perniciosa. Indeed, the successful prevention of diseases caused by OA-producing fungi has already been well demonstrated in transgenic plants expressing FvOXDC (Cunha et al. 2010; Dias et al. 2006).

\section{RESULTS}

\section{Expression of FvOXDC in transgenic tobacco.}

Tobacco leaf discs were transformed using the construct pCambOxDc, designed for high FvOXDC expression in plants (Dias et al. 2006). This construct contains an OXDC cDNA from $F$. velutipes (FvOXDC) under control of the doubled Cauliflower mosaic virus (CaMV) $35 \mathrm{~S}$ promoter and a sequence enhancer of Alfalfa mosaic virus (AMV). Twelve regenerated tobacco plants in hygromycin-containing medium representing distinct transformation events were screened for the presence of the transgene. Polymerase chain reaction (PCR) was carried out using a pair of primers specifically designed to amplify a 502-bp fragment of the FvOXDC cDNA. A single band of the expected size was obtained in all transgenic plants evaluated (Fig. 1A). We have also carried out genomic Southern hybridi- zation with FvOXDC cDNA as probe, confirming that only the transgenic plants gave hybridization bands (data not shown). All the transgenic tobacco plants exhibited a normal phenotype and were fertile.

Analysis of the FvOXDC expression was carried out in up to seven transgenic plants by reverse-transcriptase (RT)-PCR. All the analyzed plants have expressed $F v O X D C$ but differences in the transcript levels were observed among the transgenic plants (Fig. 1B). The transgenic lines L7, L6, L5, and L4 showed higher levels of FvOXDC transcripts, whereas L10 and L3 had lower transcript levels.

\section{Transgenic tobacco plants can degrade $\mathrm{OA}$ and generate formic acid in vivo.}

The ability of transgenic plants to degrade OA and generate formic acid by the action of FvOXDC was tested in vivo. Total $\mathrm{OA}$ and formic acid contents were analyzed in leaves of transgenic and control plants by high-performance liquid chromatography (HPLC). The transgenic plants showed a significant decrease in the levels of OA compared with the control plants, which varied from 18 to $75 \%$, depending on the transgenic line (Fig. 2A). On the other hand, the formic acid content increased from 9 to $27 \times$ in the transgenic plants compared with the control plants (Fig. 2B). The results demonstrated that all transgenic plants evaluated possess an enzymatically active FvOXDC.

\section{Transgenic tobacco expressing FvOXDC are resistant to exogenous $\mathrm{OA}$ application.}

To test the effects of the exogenous application of OA in the transgenic plants, photosynthetically active leaves from control and transgenic plants were excised and the petioles were immediately dipped and vacuum infiltrated in OA solution. Initially, leaves of control plants were dipped into solution containing different OA concentrations that established $20 \mathrm{mM} \mathrm{OA}(\mathrm{pH} 4)$ as the necessary concentration to induce leaf wilting and necrosis (data not shown). After $24 \mathrm{~h}$, OA-treated leaves of most transgenic plants did not wilt or necrose like those of control plants. Leaves of the transgenic plants were resistant to OA even after $48 \mathrm{~h}$, whereas leaf tissues of OA-treated control plants was found to be completely wilted and necrosed (Fig. 3). This result shows that the expression of FvOXDC in transgenic plants confers resistance to wilting and necrosis induced by OA.

\section{FvOXDC-expressing tobacco plants are resistant to MpNEP2.}

Similarly to NPP1 of Phytophthora spp. (Fellbrich et al. 2002), MpNEP are able to induce necrosis in tobacco, as previously described (Garcia et al. 2007). Based on the different results obtained in the tests carried out above (Figs. 2 and 3), three transgenic plants were selected for the assay. MpNEP2 was inoculated in leaves from control and transgenic plants as described for OA. Leaves of control plants were treated with either phosphate (PB) buffer or MpNEP2. Typical symptoms caused by MpNEP2 were observed after $48 \mathrm{~h}$ in leaves of the control plants. The symptoms were characterized by chlorosis followed by necrosis, starting near the margin and then proceeding to the center of the leaves (Fig. 4). Transgenic leaves showed remarkable resistance to MpNEP2 in comparison with control leaves. L5 and L7 transgenic leaves were resistant to MpNEP2 even after $96 \mathrm{~h}$, when control leaves turned completely necrosed; on the other hand, L3 leaves exhibited severe symptoms of water soaking at that time. The results seem to be consistent with the levels of expression (Fig. 1B) and in vivo activity of FvOXDC (Fig. 2) in the transgenic plants.

The extent of cell death in MpNEP2-treated leaves of control and transgenic plants was assessed after $96 \mathrm{~h}$ by measuring the water leakage caused by membrane damage. As expected, 
all the transgenic plants showed a significantly reduced (25 to $90 \%$ ) water leakage when compared with the control plants (Fig. 5). L5 leaves showed more resistance to water leakage than L3 and L10, which correlated with the symptoms observed in Figure 4. Taken together, these data indicate that high FvOXDC activity is closely associated with the inhibition of cell death induced by MpNEP2.

\section{FvOXDC confers resistance to $\mathrm{OA}$ and MpNEP2} by inhibiting ROS generation.

A growing body of evidence suggests that ROS can activate PCD in mammalian and plant cells (Jabs 1999). In plant tissues, some conditions leading to ROS formation and subsequent PCD include senescence, cold, osmotic stress, UV radiation, and inoculation with avirulent pathogens leading to hypersensitive response (HR) (Van Breusegem and Dat 2006). ROS also appear to trigger PCD in OA-treated (Kim et al. 2008) and NLP-treated plant tissues (Bae et al. 2006; Fellbrich et al. 2002; Jennings et al. 2001; Qutob et al. 2006; Schouten et al. 2008). Therefore, we were interested in determining whether the resistance conferred by FvOXDC to OA- and MpNEP2-induced cell death, or PCD, involves the inhibition of ROS generation. Leaf disks of control and L6 transgenic plants were treated with OA, MpNEP2, and a combination of both elicitors for $24 \mathrm{~h}$; then, the disks were stained with 3,3'-diaminobenzidine (DAB), in order to detect the production of $\mathrm{H}_{2} \mathrm{O}_{2}$ (Kim et al. 2008). L6 was selected for this assay based on the high level of expression and in vivo activity of FvOXDC. Nontreated leaf disks of control and transgenic plants showed a lightly staining mainly at the periphery, as a result of wounding (Fig. 6). OA- and MpNEP2-treated leaf disks of control plants were more heavily stained throughout and clearly distinct from the nontreated disks. The intensity of stain-

\section{$\begin{array}{lllllllllllllllll}\text { A } & M & \text { W } & \text { C+ } & \text { L1 } & \text { L2 } & \text { L3 } & \text { L4 } & \text { L5 } & \text { L6 } & \text { L7 } & \text { L8 } & \text { L9 } & \text { L10 } & \text { L11 } & \text { L12 }\end{array}$}
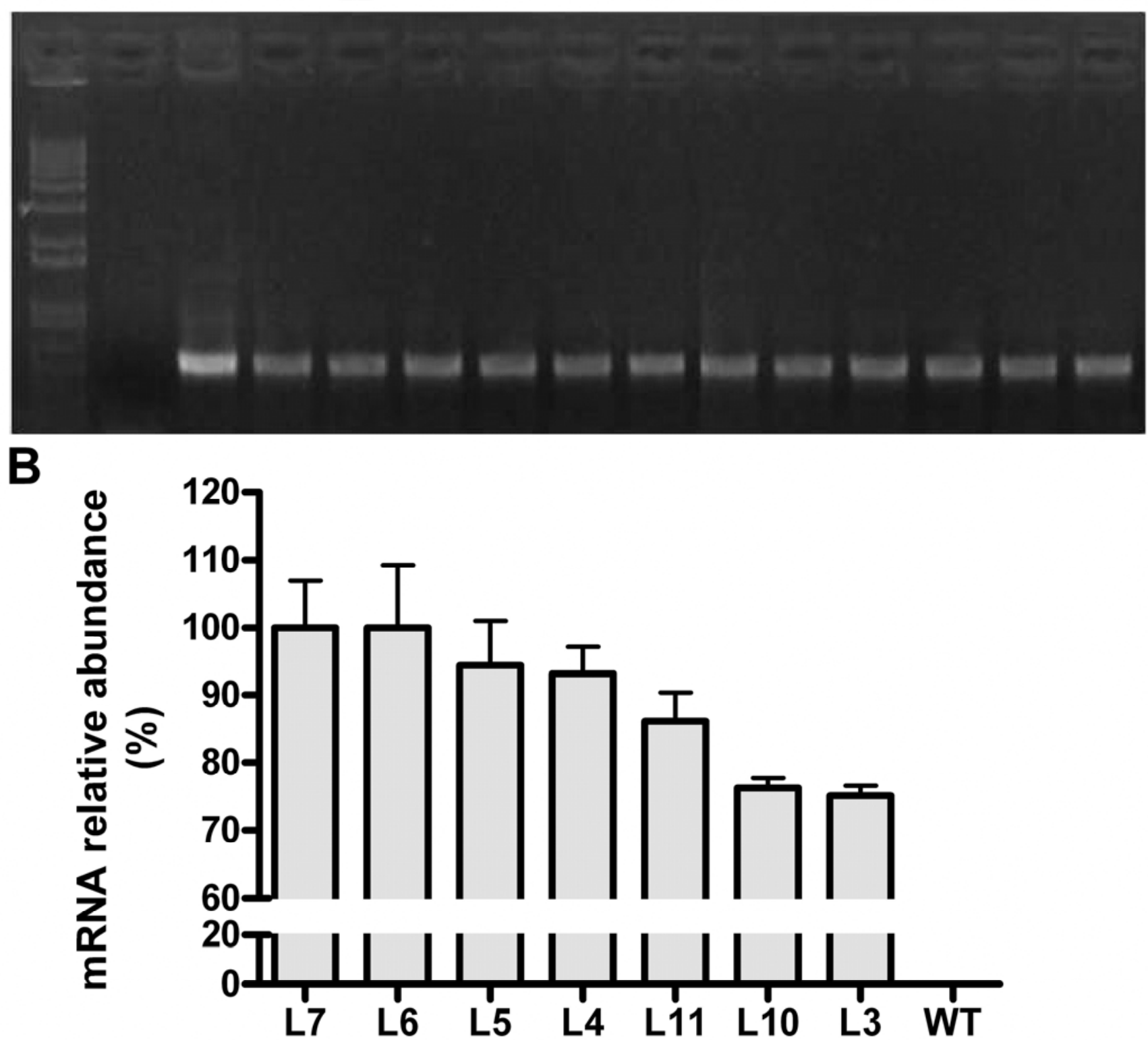

Fig. 1. Molecular analysis of representative transgenic tobacco plants. A, Polymerase chain reaction (PCR) amplification of transgene using genomic DNA from nontransformed (wild-type [WT]) and transgenic (L1 to L12) plants. C+, pCambiaOxDc plasmid DNA. Molecular weight marker (M) is indicated on the left. B, Analysis of Flammulina velutipes oxalate decarboxylase mRNA expression in WT and transgenic plants. Expression profiles were determined by relative quantitative reverse-transcription PCR using the QuantumRNA 18S Internal Standards kit (Ambion Inc., Austin, TX, U.S.A.). Data are presented as means \pm standard deviation of three biological replicates. 
ing has increased when the control leaf disks were treated simultaneously with OA and MpNEP2, suggesting a synergic effect of both elicitors on the ROS generation. Conversely, the treated leaf disks of transgenic plants were not stained under any circumstance. This observation coincides with the resistance of the transgenic plants to OA- and MpNEP2-induced cell death. Thus, there is a strict relationship between the inhibition of ROS generation and the prevention of OA- and MpNEP2-induced cell death by FvOXDC.

\section{DISCUSSION}

OA and NLP play a key role in the induction of host cell death by necrotrophic fungi, which is crucial for the establish- ment and progression of pathogenesis (Van Kan 2006). Recent data indicate that the hemibiotrophic basidiomycete $M$. perniciosa also shares these conserved PCD elicitors with necrotrophic ascomycetes in order to assist the transition from biotrophic to the necrotrophic phase, nutrient acquisition, fungal development, and life-cycle completion (Ceita et al. 2007; Garcia et al. 2007; Rio et al. 2008). A common mechanism mediating OA- and NLP-induced PCD is the generation of ROS (Bae et al. 2006; Fellbrich et al. 2002; Guo and Stotz 2010; Jennings et al. 2001; Kim et al. 2008; Qutob et al. 2006; Schouten et al. 2008), which may derive from the degradation of oxalate by OXO (Shetty et al. 2008). In the present study, the question of whether the overexpression of an OXDC in plants can make them resistant to cell death caused by both OA
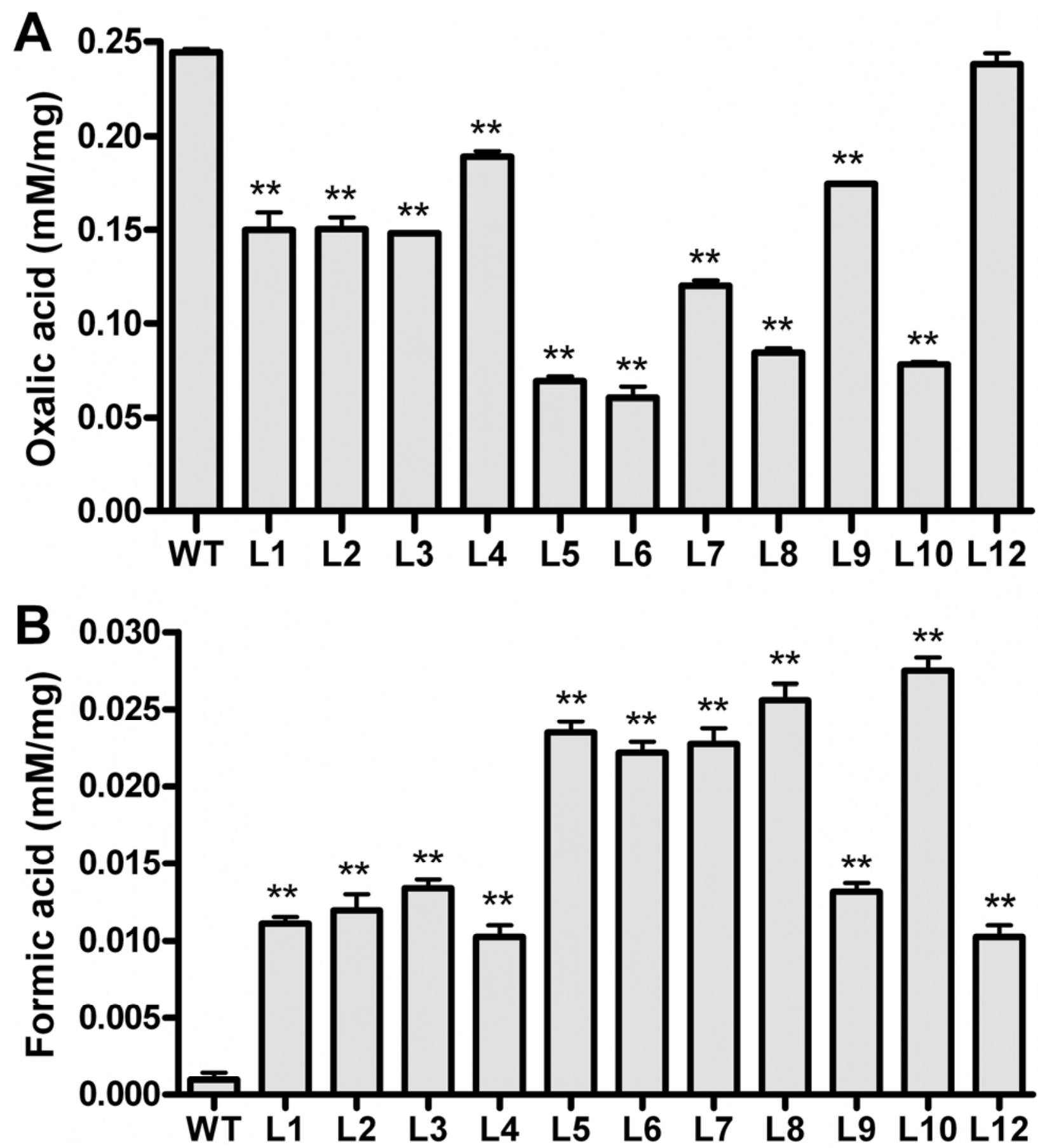

Fig. 2. Measurement of total oxalic acid (OA) and formic acid contents in leaves of wild-type (WT) and transgenic plants. A, OA and B, formic acid. Data are means \pm standard deviation of three biological replicates; ** indicates significantly different from WT, according to Student's $t$ test $(P \leq 0.01)$. 
and NLP was analyzed. Toward this end, we have introduced an $O X D C$ gene from $F$. velutipes $(F v O X D C)$ in transgenic tobacco plants. A number of independent transformants were obtained that exhibited a normal phenotype and were fertile. The transgenic plants were demonstrated to express high levels of functional enzyme. Our data indicate that the transgenic plants can resist wilting and necrosis caused by OA. Foliar wilting in response to $\mathrm{OA}$ is known to occur via opening of stomatal pores (Guimaraes and Stotz 2004), in a regulation process that involves the activation of the plasma membrane $\mathrm{H}^{+}$-ATPase and the concomitant inhibition of abscissic acidinduced ROS accumulation in the guard cells (Guo and Stotz 2010). Consistent with our observations, several reports have shown that transgenic plants overexpressing OXO (Berna and Bernier 1997; Donaldson et al. 2001; Dong et al. 2008; Hu et al. 2003; Liang et al. 2001; Livingstone et al. 2005; Thompson et al. 1995) and OXDC (Cunha et al. 2010; Dias et al. 2006; Kesarwani et al. 2000) are resistant to OA-producing pathogens. However, the exact mechanism involved in this resistance remains unclear. Based on our findings and in the recent observation that OA is an efficient elicitor of PCD (Kim et al. 2008), we propose the suppression of OA-induced PCD as a key mechanism inhibiting the colonization of host tissues by necrotrophic fungi in transgenic plants overexpressing $\mathrm{OXO}$ and OXDC.

A major breakthrough was the observation that high FvOXDC activity is also able to inhibit cell death induced by MpNEP2. To our knowledge, this is the first demonstration of a gene conferring resistance against NLP in plants. Our result suggested that plants with the ability to degrade oxalate may be protected from this PCD elicitor, establishing that oxalate is an important determinant of NLP-induced cell death. Oxalate is a substrate for the germin family of plant proteins that have been isolated from many higher plants, including both dicotyledonous and monocotyledonous species (Hu et al. 2003). Yet, only those from monocots are referred to in the literature as "true germins" by possessing OXO activity (Davidson et al. 2009). Germin-like proteins (GLP) present in dicots are of unknown enzyme activity or do not possess OXO activity (Dunwell et al. 2008). On the other hand, only dicots have been shown to be susceptible to the effects of NLP, whereas monocots are insensitive (Bailey 1995; Fellbrich et al. 2002; Gijzen and Nürnberger 2006; Keates et al. 2003; Mattinen et al. 2004; Pemberton et al. 2005; Qutob et al. 2006; Schouten et al. 2008; Staats et al. 2007; Veit et al. 2001). Taken together with these observations, our result suggests that the insensitivity of monocots to NLP may be correlated with their inherent ability to efficiently degrade oxalate. We are currently testing this hypothesis.

In animals, ROS such as $\mathrm{H}_{2} \mathrm{O}_{2}$, superoxide ion $\left(\mathrm{O}_{2}^{-}\right)$, and nitric oxide (NO) are well-recognized triggers of cell death (Jabs 1999). In contrast, the role of ROS in the induction, signaling, and execution of plant PCD has been revealed only recently (Van Breusegem and Dat 2006). OA and NLP also appear to activate ROS in order to cause PCD in the host (Bae et al. 2006; Fellbrich et al. 2002; Jennings et al. 2001; Kim et al. 2008; Qutob et al. 2006; Schouten et al. 2008), which is consistent with the strategy of necrotrophic plant pathogens. To understand the underlying mechanism involved in the resistance of the transgenic plants to OA- and MpNEP2-induced cell death, or PCD, DAB staining of leaf discs was used to demonstrate production of $\mathrm{H}_{2} \mathrm{O}_{2}$ as an indicative for ROS generation (Kim et al. 2008). Our data confirmed a positive DAB staining induced by OA and MpNEP2 in control plants, which
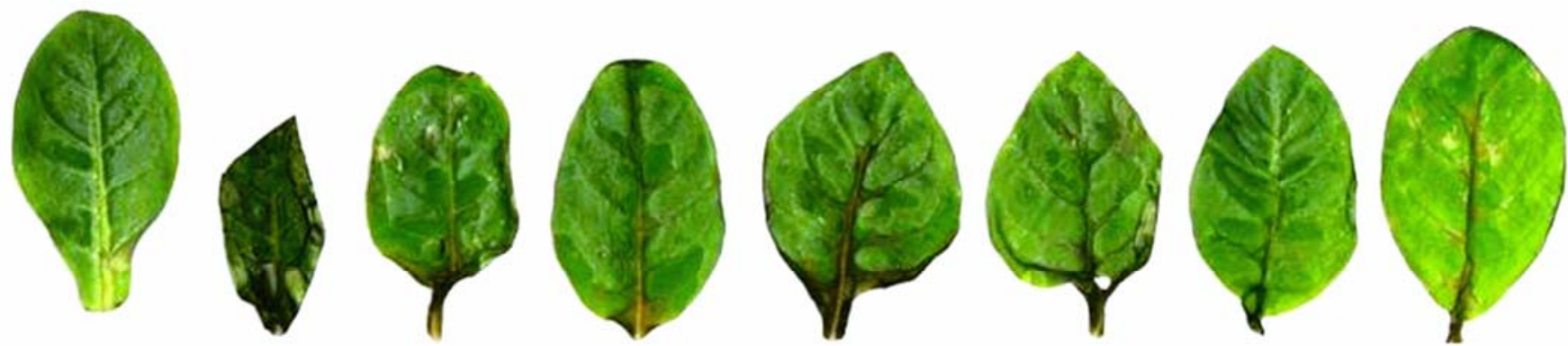

\section{[PB-buffer] [OA]}

WT
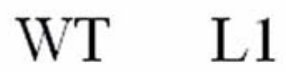

L3
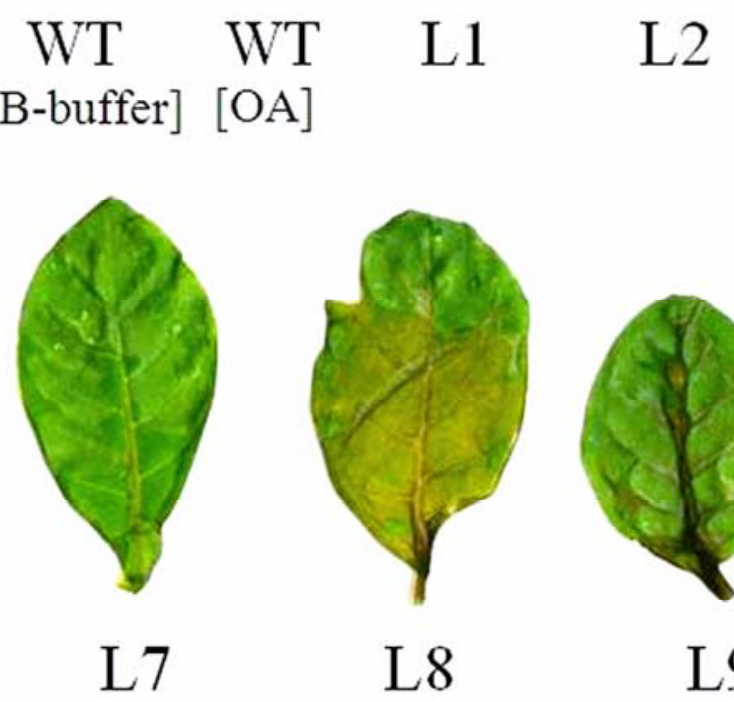
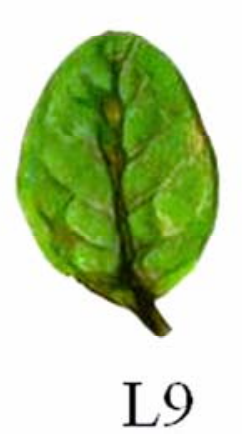
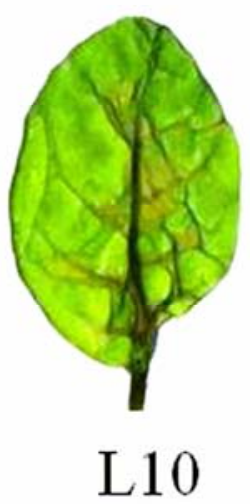

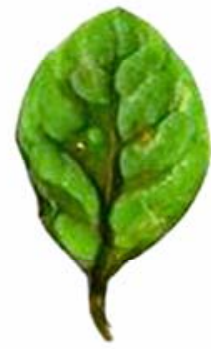

L11

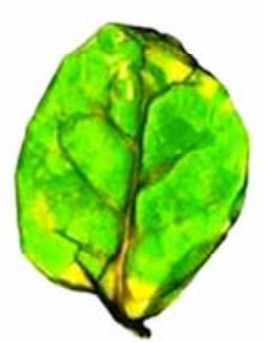

L12

Fig. 3. Sensitivity of tobacco plants to oxalic acid (OA)-induced wilting and necrosis. Excised leaves from wild-type (WT) and transgenic plants were treated with $20 \mathrm{mM} \mathrm{OA}(\mathrm{pH} 4.0)$ or phosphate (PB) buffer (as a control). Symptoms were recorded after $48 \mathrm{~h}$. Representative results of experiments performed in triplicate are shown. 
was even enhanced by the synergic effect of both PCD elicitors on the ROS formation. On the other hand, the production of ROS was completely abolished in the transgenic plants. This result suggests the inhibition of ROS as the mechanism involved in the resistance of the FvOXDC-overexpressing plants to OA- and MpNEP2-induced cell death. In addition, it provides evidence of the cellular process or pathway required for the PCD-inducing activity of OA and NLP: ROS activation through the conversion of oxalate to $\mathrm{H}_{2} \mathrm{O}_{2}$. As discussed, this reaction is catalyzed by $\mathrm{OXO}$, whose activity has not been demonstrated for GLP of dicotyledonous species, although proteins containing $\mathrm{OXO}$ activity other than the germin-type
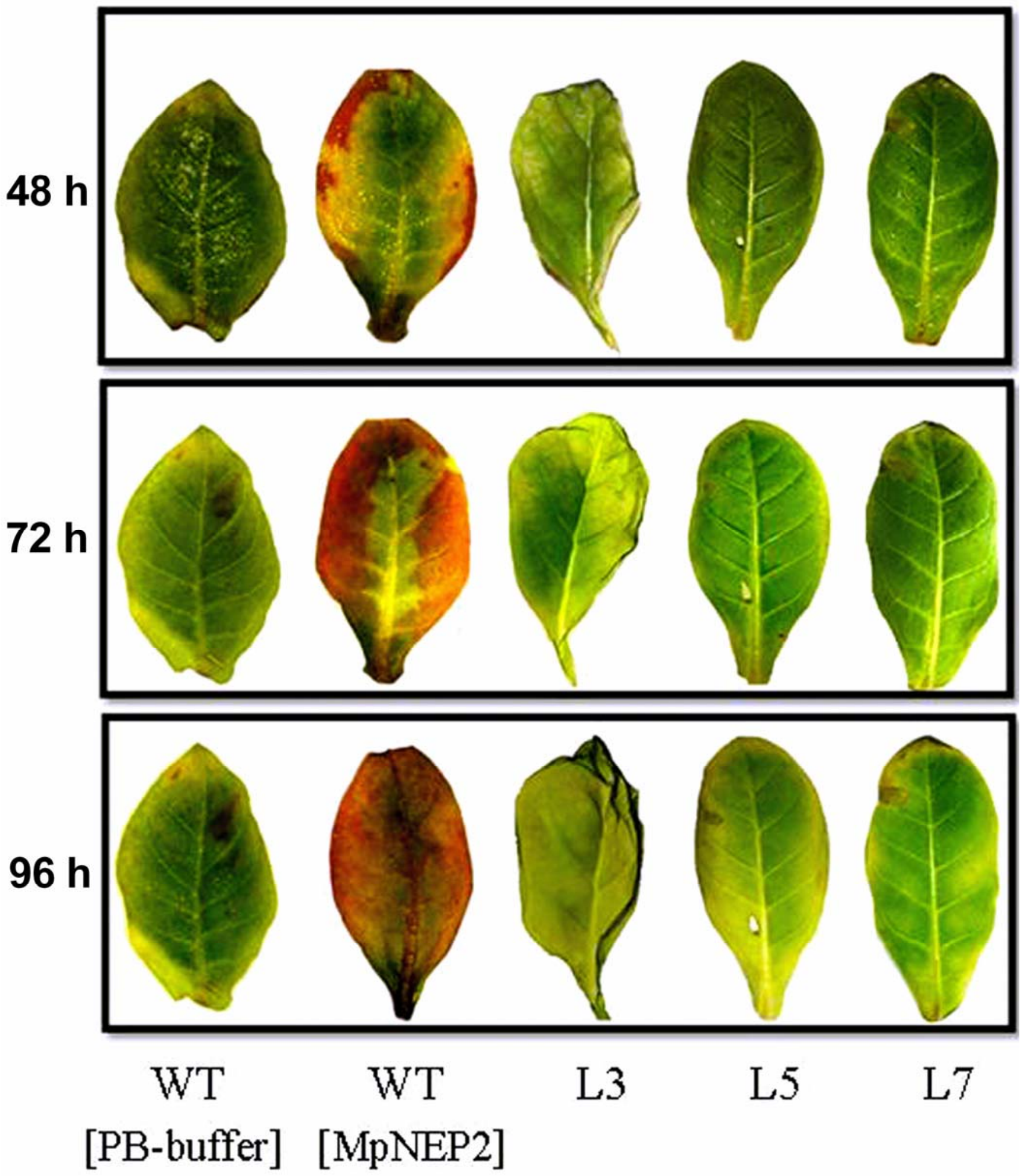

Fig. 4. MpNEP2-induced necrosis in tobacco plants. Excised leaves from wild-type (WT) and transgenic plants were treated with $1.4 \mu \mathrm{M} \mathrm{MpNEP} 2(\mathrm{pH}$ 6.0) or phosphate (PB) buffer (as a control). Symptoms were recorded after 48, 72, and $96 \mathrm{~h}$. Results shown are representative of experiments performed in triplicate. 
have been recently discovered in beet and spinach (Davidson et al. 2009). Thus, a possibility is that the OA- and NLPinduced reaction of oxalate oxidation could also be catalyzed by the pathogen in order to trigger ROS and the cell death process. Equally, the pathogen may regulate the OXO activity of dicot proteins other than germins. The observation that the basidiomycete Ceriporiopsis subvermispora contains functional OXO genes (Aguilar et al. 1999; Escutia et al. 2005) is consis-

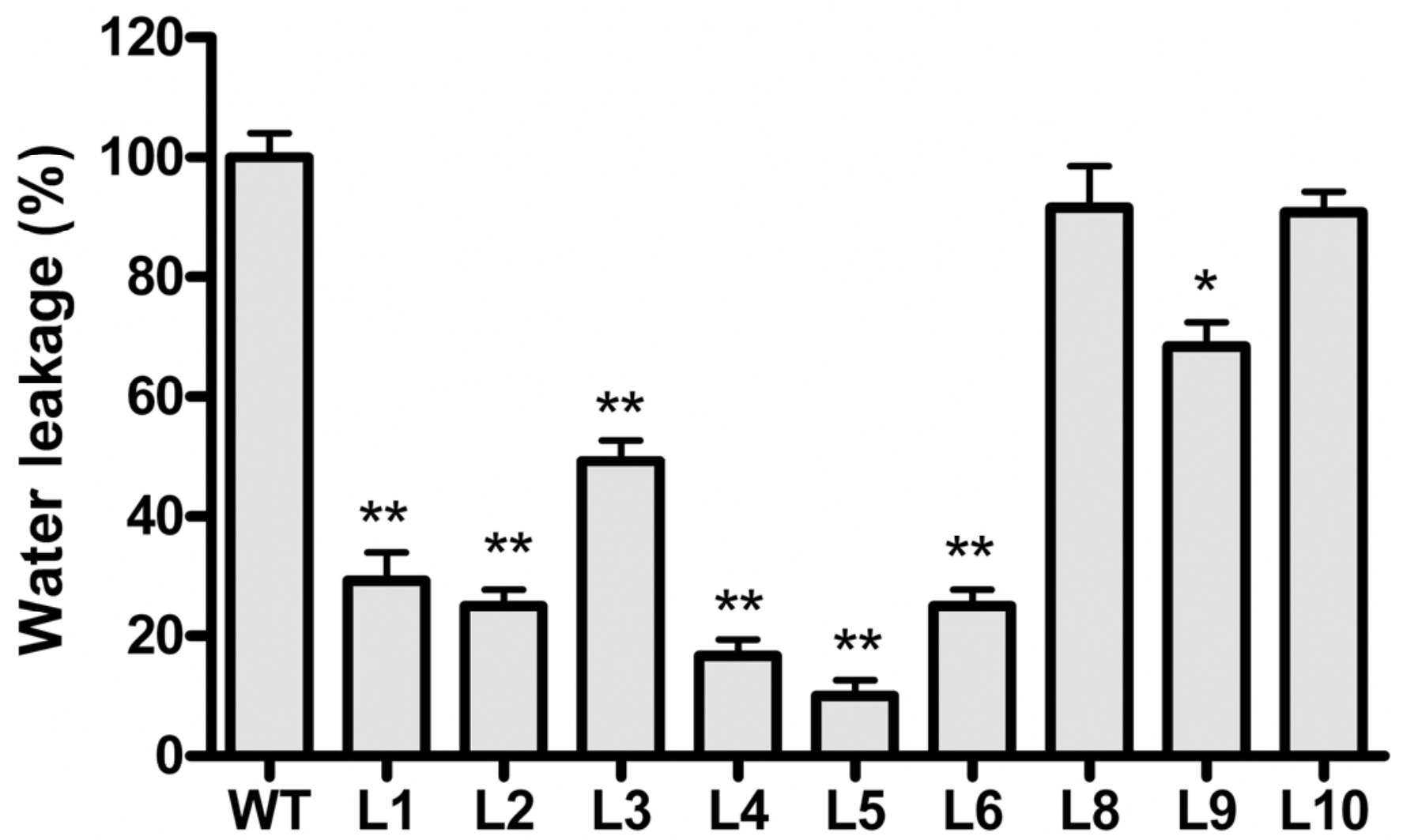

Fig. 5. Water leakage in tobacco leaves treated with MpNEP2. Excised leaves from wild-type (WT) and transgenic plants were treated with $1.4 \mu \mathrm{M}$ MpNEP2 (pH 6.0) and water leakage was recorded after $96 \mathrm{~h}$. Data are means \pm standard deviation of three biological replicates; * and** indicate significantly different from WT at $P \leq 0.05$ or 0.01 , respectively, according to Student's $t$ test.

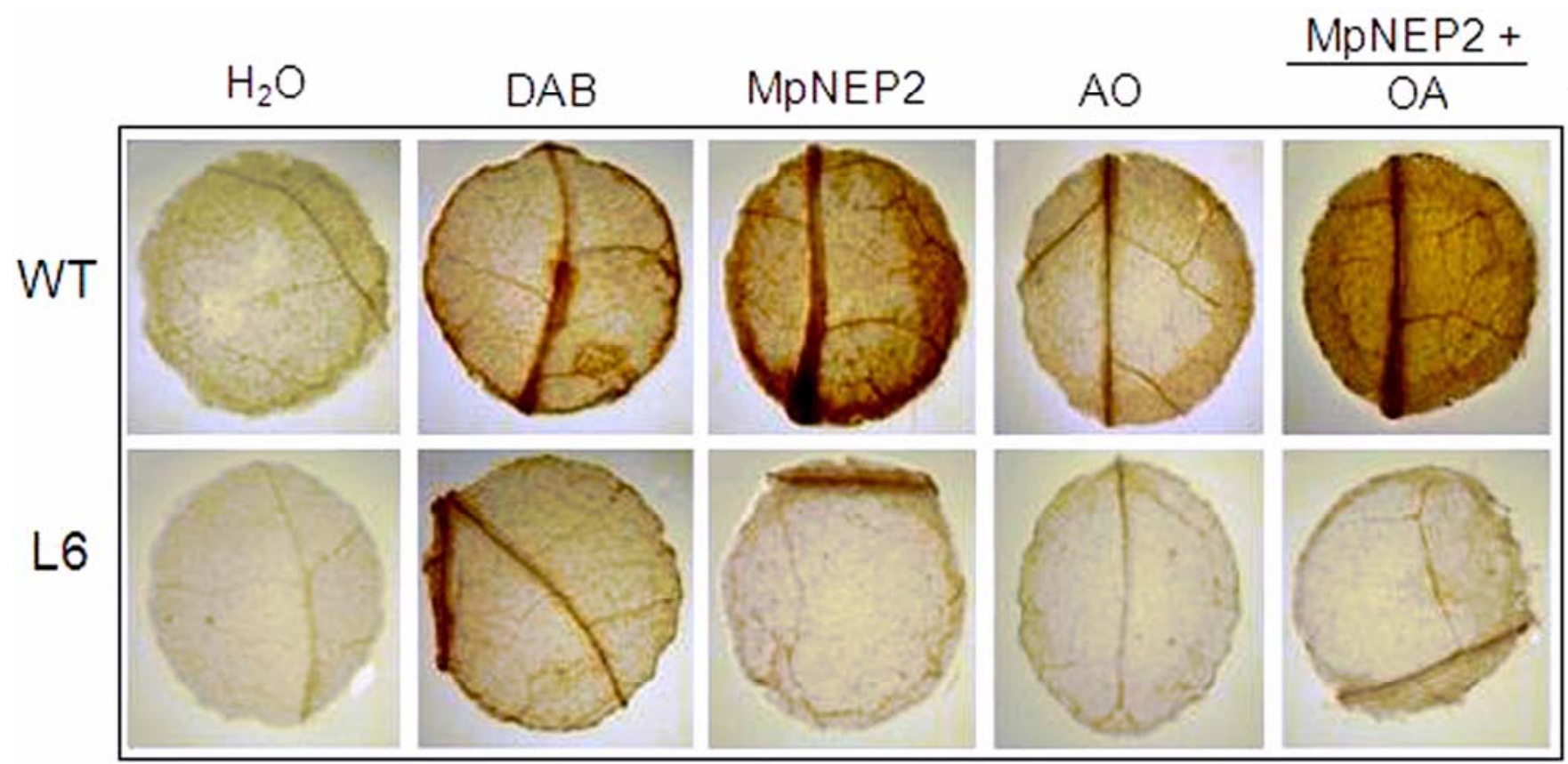

Fig. 6. Involvement of reactive oxygen species (ROS) in oxalic acid (OA)- and MpNEP2-induced cell death in tobacco leaf disks. Leaf disks from wild-type (WT) and transgenic plants were treated with $20 \mathrm{mM}$ OA, $1.4 \mu \mathrm{M} \mathrm{MpNEP} 2$, or $20 \mathrm{mM} \mathrm{OA}+1.4 \mu \mathrm{M} \mathrm{MpNEP} 2 . \mathrm{H}_{2} \mathrm{O}_{2}$ production (revealed by reddish-brown stain) was detected by 3,3'-diaminobenzidine (DAB) staining $24 \mathrm{~h}$ after the treatments. Control treatments were treated with water or water $+\mathrm{DAB}$. Results are representative of experiments performed in triplicate. 
tent with the first premise. Analysis of the $M$. perniciosa draft genome has also revealed the presence of a putative gene encoding OXO (data not shown).

Hemibiotrophic pathogens compose a diverse group of organisms with an initial biotrophic phase when infection is established, followed by a necrotrophic phase when the pathogen completes its life cycle (Oliver and Ipcho 2004). Our study reinforces the previous findings about the contribution of oxalate and MpNEP2 for PCD induction, which is required for the establishment of a necrotrophic relationship of $M$. pernicios $a$ with host tissues in the later stage of infection (Ceita et al. 2007; Garcia et al. 2007; Rio et al. 2008). The significance of having both OA and NLP to initiate host PCD and tissue necrosis has been well illustrated for successful infection by the necrotrophic plant pathogens S. sclerotiorum and Botrytis cinerea (Choquer et al. 2007; Van Kan 2006). We also go further than the initial findings to demonstrate that this PCD is ROS dependent, in a pathway involving the conversion of oxalate to $\mathrm{H}_{2} \mathrm{O}_{2}$. The observation that a large amount of $\mathrm{H}_{2} \mathrm{O}_{2}$ can be observed in the infected tissues during the late stage of infection, at the same sites where calcium oxalate crystals had previously been detected (Ceita et al. 2007), is consistent with this idea. A correlation between hemibiotrophic pathogen growth at the late stages of their life cycle and large quantities of $\mathrm{H}_{2} \mathrm{O}_{2}$ has also been reported in other host-pathogen systems (Shetty et al. 2008). It has been concluded that $\mathrm{H}_{2} \mathrm{O}_{2}$ was necessary for successful infection in such host-pathogen systems. This seems to be a valid conclusion in the M. perniciosa compatible interaction with host plants (Ceita et al. 2007). The ability to colonize and proliferate in an environment with high concentrations of ROS shows, on the other hand, that such pathogens have efficient systems enabling them to neutralize these harmful compounds. Indeed, a complete ROS detoxification system has been found in the genome of $M$. perniciosa, including genes encoding to superoxide dismutases, catalases, peroxiredoxins, glutathiones, thioredoxins, and manganese-dependent peroxidases (Mondego et al. 2008).

In conclusion, our results suggest that ROS generation induced by OA and NLP is a key mechanism triggering PCD in tissues infected with these PCD elicitors, in a pathway that relies on the conversion of oxalate into $\mathrm{H}_{2} \mathrm{O}_{2}$. Our data also show that FvOXDC may represent a potential source of resistance against OA- and NEP-producing pathogens such as $M$. perniciosa. We are currently testing this hypothesis through the overexpression of OXDC in tomato and cacao.

\section{MATERIALS AND METHODS}

\section{Plant material.}

Wild-type (WT) tobacco (Nicotiana tabacum 'Havana') was grown from seed in a growth room at $26 \pm 2{ }^{\circ} \mathrm{C}$ with 16 -h light periods. Surface-sterilization was performed by immersion of the seed in $70 \%$ ( $\mathrm{vol} / \mathrm{vol}$ ) ethanol for $1 \mathrm{~min}$, followed by 20 min in a $2.5 \%(\mathrm{vol} / \mathrm{vol})$ sodium hypochlorite solution containing $0.1 \%$ (vol/vol) Tween-20 and then four rinses in sterile distilled water. Seed were germinated in Magenta boxes (SigmaAldrich, St. Louis) with $50 \mathrm{ml}$ of half-strength Murashige and Skoog $(1 / 2 \mathrm{MS})$ medium containing $1 / 2 \mathrm{MS}$ salts (Murashige and Skoog 1962), myo-inositol at $50 \mathrm{mg} / \mathrm{liter}$, Nitsch vitamins (Nitsch 1969), sucrose at $20 \mathrm{~g} /$ liter (pH 5.8), and solidified with $0.8 \%$ agar (Sigma-Aldrich). Leaf disks were obtained from 8-week-old plants using a 10-mm-diameter cork borer (Boekel Scientific, Feasterville, PA, U.S.A.).

\section{Agrobacterium strain and plasmid.}

Agrobacterium tumefaciens EHA 105, containing the vector pCambiaOxDc, was used in all tobacco transformations. This vector contains an oxalate decarboxylase $(F v O X D C)$ coding sequence of $F$. velutipes, under the control of the doubled $35 \mathrm{~S}$ promoter from CaMV and a sequence enhancer from AMV, and the hygromycin phosphotransferase II (hptII) selectable marker gene, driven by the CaMV $35 \mathrm{~S}$ promoter (Dias et al. 2006).

\section{Plant transformation.}

Leaf discs from in vitro-grown tobacco plants were transformed as previously described (Alvim et al. 2001). The shoots obtained were rooted on phytohormone-free medium containing hygromycin at $10 \mathrm{mg} /$ liter. All transformed plants $\left(\mathrm{T}_{0}\right.$ plants) were micropropagated and maintained in the growth room at $26 \pm 2{ }^{\circ} \mathrm{C}$ with a 16 -h photoperiod.

\section{Molecular analysis of transgenic plants.}

Total DNA was isolated from tobacco leaves using the cetyltrimethylammonium bromide method (Doyle and Doyle 1987). PCR was carried out using the primers OXDC $873\left(5^{\prime}\right.$ TGGGCTCGACAGAGGAGAAG-3') and OXDC 371 (5'-CT CGGCAGCAGAATGAGGTC- $3^{\prime}$ ), as described (Dias et al. 2006). Total RNA was isolated from tobacco leaves using the phenol method (Jones et al. 1985). Reverse transcription was carried out using the RETROscript kit (Ambion Inc., Austin, TX, U.S.A.), following the manufacturer's instructions. Prior to RT-PCR reactions, total RNA was treated with DNase I (FPLC pure; Amersham Pharmacia Biotech, Piscataway, NJ, U.S.A.) to avoid DNA contamination (DNase I at $100 \mathrm{U} / \mathrm{\mu g}$ of total RNA). The relative abundance of $O X D C$ mRNA in the transgenic plants was assessed employing the QuantumRNA 18S Internal Standards kit (Ambion Inc., Austin, TX, U.S.A.) and the pair of primers OXDC 873 and OXDC 371. Reactions were performed in triplicate and the PCR products were quantified on agarose gels using the program KODAK $1 D$ v 3.5. In each sample, the signal obtained for the OXDC amplicon was divided by the signal obtained for the $18 \mathrm{~S}$ amplicon.

\section{OA and formic acid measurements.}

Organic acid extraction and quantification was carried out as previously described (Keates et al. 2000), with some modifications. Approximately $6 \mathrm{mg}$ of the freeze-dried and ground leaves (triplicates) of each individual plant was suspended in 1 $\mathrm{ml}$ of extraction buffer $\left(\mathrm{H}_{2} \mathrm{SO}_{4}\right.$ at $4 \mathrm{mmol} /$ liter, dithiothreitol at $5 \mathrm{mmol} / \mathrm{liter}$, and $0.01 \%$ insoluble polyvinylpolypyrrolidone at $10 \mathrm{mg} / \mathrm{ml})$. Extracts were agitated for $15 \mathrm{~min}$ in the vortex and then centrifuged at $15,000 \times g$ for $20 \mathrm{~min}$ at room temperature. The supernatant was filtered $(0.45 \mu \mathrm{m})$ and $100 \mu \mathrm{l}$ was applied in the HPLC for analysis and detection of OA and formic acid (column of ionic exclusion Bio-Rad Aminex HPX-87H, 300 by $7.8 \mathrm{~mm}$, with flow of $0.7 \mathrm{ml} / \mathrm{min}$, at $25^{\circ} \mathrm{C}$, using the automatized system of HPLC ÄKTAbasic) (GE Healthcare, Piscataway, NJ, U.S.A.). The HPLC data were integrated and analyzed using the software UNICORN v. 5.0. OA and formic acid were measured at $210 \mathrm{~nm}$. Standard aliquots of OA and formic acid with known concentrations were used for the standard curve preparation.

\section{OA and MpNEP2 sensitivity assay of leaves.}

Heterologous expression and purification of MpNEP2 were previously described (Garcia et al. 2007). Photosynthetically active leaves (triplicates) from WT and transgenic plants were excised, and the petioles were immediately dipped in $20 \mathrm{mM}$ $\mathrm{OA}(\mathrm{pH} 4.0)$ or $1.4 \mu \mathrm{M}$ MpNEP2 (pH 6.0) solutions and subjected to vacuum infiltration for $20 \mathrm{~min}$. Negative control was imposed by dipping and vacuum infiltrating the leaves in $\mathrm{PB}$ buffer with $\mathrm{pH}$ adjusted to $4.0(\mathrm{OA})$ or 6.0 (MpNEP2) using hydrochloric acid. Leaves were incubated in a growth room for 
$96 \mathrm{~h}$ at $26 \pm 2^{\circ} \mathrm{C}$ under a 16-h photoperiod. The extent of necrosis was recorded after $24,48,72$, and $96 \mathrm{~h}$.

\section{Measurement of cell death.}

Cell death was quantified in leaves from WT and transgenic plants treated with MpNEP2 by measuring the water leakage resulting from membrane damage. The experiment was carried out as described above. Water leakage was expressed as percentage of total water release, quantified by the difference in the fresh weight of leaves between 0 and $96 \mathrm{~h}$ after MpNEP2 inoculation.

\section{Detection of ROS.}

In situ $\mathrm{H}_{2} \mathrm{O}_{2}$ was detected by DAB staining as described (Kim et al. 2008). Leaf disks (triplicates) from WT and transgenic plants were treated with i) $20 \mathrm{mM} \mathrm{OA}$, ii) $1.4 \mu \mathrm{M}$ MpNEP2, or iii) $20 \mathrm{mM} \mathrm{OA}+1.4 \mu \mathrm{M} \mathrm{MpNEP} 2$. The samples were immersed in DAB solution $(\mathrm{pH} 7.5)$ at $1 \mathrm{mg} / \mathrm{ml}$ and infiltrated using vacuum for $20 \mathrm{~min}$. After incubation in the dark at room temperature for $24 \mathrm{~h}$, samples were boiled in a solution containing $96 \%$ ethanol for 20 min and rinsed twice with $50 \%$ ethanol. Leaf disks of control treatments were vacuum infiltrated with water alone or water plus DAB.

\section{ACKNOWLEDGMENTS}

This work was supported by research grants from Fundação de Amparo à Pesquisa do Estado da Bahia (Salvador, Brazil), The National Council for Scientific and Technological Development (Brasília, Brazil), and Coordination of Higher Education and Graduate Training (Brasília, Brazil).

\section{LITERATURE CITED}

Aguilar, C., Urzúa, U., Koenig, C., and Vicuña, R. 1999. Oxalate oxidase from Ceriporiopsis subvermispora: Biochemical and cytochemical studies. Arch. Biochem. Biophys. 366:275-282.

Alvim, F. C., Carolino, S. M. B., Cascardo, J. C. M., Nunes, C. C., Martinez, C. A., Otoni, W. C., and Fontes, E. P. B. 2001. Enhanced accumulation of $\mathrm{BiP}$ in transgenic plants confers tolerance to water stress. Plant Physiol. 126:1042-1054.

Amsellem, Z., Cohen, B. A., and Gressel, J. 2002. Engineering hypovirulence in a mycoherbicidal fungus for efficient weed control. Nat. Biotechnol. 20:1035-1039.

Bae, H., Moon, S. K., Richard, C. S., Bae, H.-J., and Bailey, B. 2006. Necrosis and ethylene inducing peptide from Fusarium oxysporum induces a complex cascade of transcripts associated with signal transduction and cell death in Arabidopsis. Plant Physiol. 141:1056-1067.

Bailey, B. A. 1995. Purification of a protein from culture filtrate of Fusarium oxysporum that induces ethylene and necrosis in leaves of Erythroxylum coca. Phytopathology 85:1250-1255.

Bashi, Z. D., Hegedus, D. D., Buchwaldt, L., Rimmer, S. R., and Borhan, M. H. 2010. Expression and regulation of Sclerotinia sclerotiorum necrosis and ethylene-inducing peptides (NEPs). Mol. Plant Pathol. 11:4353.

Bateman, D. F., and Beer, S. V. 1965. Simultaneous production and synergistic action of oxalic acid and polygalacturonase during pathogenesis by Sclerotiorum rolfsii. Phytopathology 55:204-211.

Berna, A., and Bernier, F. 1997. Regulated expression of a wheat germin gene in tobacco: Oxalate oxidase activity and apoplastic localization of the heterologous protein. Plant Mol. Biol. 33:417-429.

Ceita, G. O., Macêdo, J. N. A., Santos, T. B., Alemanno, L., Gesteira, A. S., Micheli, F., Mariano, A. C., Gramacho, K. P., Silva, D. C., Meinhardt, L. W., Mazzafera, P., Pereira, G. A. G., and Cascardo, J. C. M. 2007. Involvement of calcium oxalate degradation during programmed cell death in Theobroma cacao tissues triggered by the hemibiotrophic fungus Moniliophthora perniciosa. Plant Sci. 173:106-117.

Cessna, S. G., Sears, V. E., Dickman, M. B., and Low, P. S. 2000. Oxalic acid, a pathogenicity factor for Sclerotinia sclerotiorum, suppresses the oxidative burst of the host plant. Plant Cell 12:2191-2200.

Choquer, M., Fournier, E., Kunz, C., Levis, C., Pradier, J.-M., Simon, A., and Viaud, M. 2007. Botrytis cinerea virulence factors: New insights into a necrotrophic and polyphageous pathogen. FEMS (Fed. Eur. Microbiol. Soc.) Microbiol. Lett. 277:1-10.

Cunha, W. G., Tinoco, M. L. P., Pancoti, H. L., Ribeiro, R. E., and Aragão,
F. J. L. 2010. High resistance to Sclerotinia sclerotiorum in transgenic soybean plants transformed to express an oxalate decarboxylase gene. Plant Pathol. 59:654-660.

Davidson, R. M., Reeves, P. A., Manosalva, P. M., and Leach, J. E. 2009. Germins: A diverse protein family important for crop improvement. Plant Sci. 177:499-510.

Dias, B. B. A., Cunha, W. G., Morais, L. S., Vianna, G. R., Rech, E. L., Capdeville, G. de, and Aragão, F. J. L. 2006. Expression of an oxalate decarboxylase gene from Flammulina sp. in transgenic lettuce (Lactuca sativa) plants and resistance to Sclerotinia sclerotiorum. Plant Pathol. 55:187-193.

Donaldson, P. A., Anderson, T., Lane, B. G., Davidson, A. L., and Simmonds, D. H. 2001. Soybean plants expressing an active oligomeric oxalate oxidase from the wheat $g f-2.8$ (germin) gene are resistant to the oxalate-secreting pathogen Sclerotina sclerotiorum. Physiol. Mol. Plant Pathol. 59:297-307.

Dong, X., Ji, R., Guo, X., Foster, S. J., Chen, H., Dong, C., Liu, Y., Hu, Q., and Liu, S. 2008. Expressing a gene encoding wheat oxalate oxidase enhances resistance to Sclerotinia sclerotiorum in oilseed rape (Brassica napus). Planta 228:331-340.

Doyle, J. J., and Doyle, J. L. 1987. A rapid DNA isolation procedure for small quantities of fresh leaf tissue. Phytochem. Bull. 19:11-15.

Dunwell, J. M., Gibbings, J. G., Mahmood, T., and Naqvi, S. M. S. 2008 Germin and germin-like proteins: Evolution, structure, and function. Crit. Rev. Plant Sci. 27:342-375.

Escutia, M. R., Bowater, L., Edwards, A., Bottrill, A. R., Burrell, M. R., Polanco, R., Vicuña, R., and Bornemann, S. 2005. Cloning and sequencing of two Ceriporiopsis subvermispora bicupin oxalate oxidase allelic isoforms: Implications for the reaction specificity of oxalate oxidases and decarboxylases. Appl. Environ. Microbiol. 71:3608-3616.

Fellbrich, G., Romanski, A., Varet, A., Blume, B., Brunner, F., Enelhardt, S., Felix, G., Kemmerling, B., Krzymowska, M., and Nurnberger, T. 2002. NPP1, a Phytophthora-associated trigger of plant defense in parsley and Arabidopsis. Plant J. 32:375-390.

Garcia, O., Macedo, J. A., Tiburcio, R., Zaparoli, G., Rincones, J., Bittencourt, L. M., Ceita, G. O., Micheli, F., Gesteira, A., Mariano, A. C., Schiavinato, M. A., Medrano, F. J., Meinhardt, L. W., Pereira, G. A G., and Cascardo, J. C. M. 2007. Characterization of necrosis and ethylene-inducing proteins (NEP) in the basidiomycete Moniliophthora perniciosa, the causal agent of witches' broom in Theobroma cacao. Mycol. Res. 111:443-455.

Gijzen, M., and Nürnberger, T. 2006. Nep1-like proteins from plant pathogens: Recruitment and diversification of the NPP1 domain across taxa. Phytochemistry 67:1800-1807

Godoy, G., Steadman, J. R., Dickman, M. B., and Dam, R. 1990. Use of mutants to demonstrate the role of oxalic acid in pathogenicity of Sclerotinia sclerotiorum on Phaseolus vulgaris. Physiol. Mol. Plant Pathol. 37:179-191.

Griffith, G. W., Nicholson, J., Nenninger, A., Birch, R. N., and Hedger, J. N. 2003. Witches' brooms and frosty pods: Two major pathogens of cacao. N. Z. J. Bot. 41:423-435.

Guimaraes, R. L., and Stotz, H. U. 2004. Oxalate production by Sclerotinia sclerotiorum deregulates guard cells during infection. Plant Physiol. 136:3703-3711.

Guo, X., and Stotz, H. U. 2007. Defense against Sclerotinia sclerotiorum in Arabidopsis is dependent on jasmonic acid, salicylic acid, and ethylene signaling. Mol. Plant-Microbe Interact. 20:1384-1395.

Guo, X., and Stotz, H. U. 2010. ABA signaling inhibits oxalate-induced production of reactive oxygen species and protects against Sclerotinia sclerotiorum in Arabidopsis thaliana. Eur. J. Plant Pathol. 128:7-19.

Hu, X., Bidney, D. L., Yalpani, N., Duvick, J. P., Crasta, O., Folkerts, O., and $\mathrm{Lu}, \mathrm{G}$. 2003. Overexpression of a gene encoding $\mathrm{H}_{2} \mathrm{O}_{2}$-generating oxalate oxidase evokes defense responses in sunflower. Plant Physiol. 133:170-181

Jabs, T. 1999. Reactive oxygen intermediates as mediators of programmed cell death in plants and animals. Biochem. Pharmacol. 57:231-245.

Jennings, J. C., Apel-Birkhold, P. C., Mock, N. M., Baker, C. J., Anderson, J. D., and Bailey, B. A. 2001. Induction of defense responses in tobacco by the protein Nep1 from Fusarium oxysporum. Plant Sci. 161:891899.

Jones, J. D. G., Dunsmuir, P., and Bedbrook, J. 1985. High level expression of introduced chimaeric genes in regenerated transformed plants. EMBO (Eur. Mol. Biol. Organ.) J. 4:2411-2418.

Keates, S. E., Tarlyn, N. M., Loewus, F. A., and Franceschi, V. R. 2000. Lascorbic acid and L-galactose are sources for oxalic acid and calcium oxalate in Pistia stratiotes. Phytochemistry 53:433-440.

Keates, S. E., Kostman, T. A., Anderson, J. D., and Bailey, B. A. 2003. A1tered gene expression in three plant species in response to treatment with Nep1, a fungal protein that causes necrosis. Plant Physiol. 132:1610-1622. 
Kesarwani, M., Azam, M., Natarajan, K., Mehta, A., and Datta, A. 2000. Oxalate decarboxylase from Collybia velutipes: Molecular cloning and its overexpression to confer resistance to fungal infection in transgenic tobacco and tomato. J. Biol. Chem. 275:7230-7238.

Kim, K. S., Min, J. Y., and Dickman, M. B. 2008. Oxalic acid is an elicitor of plant programmed cell death during Sclerotinia sclerotiorum disease development. Mol. Plant-Microbe Interact. 21:605-612.

Liang, H., Maynard, C. A., Allen, R. D., and Powell, W. A. 2001. Increased Septoria musiva resistance in transgenic hybrid poplar leaves expressing wheat oxalate oxidase gene. Plant Mol. Biol. 45:619-629.

Livingstone, D. M., Hampton, J. L., Phipps, P. M., and Grabau, E. A. 2005. Enhancing resistance to Sclerotinia minor in peanut by expressing a barley oxalate oxidase gene. Plant Physiol. 137:1354-1362.

Mattinen, L., Tshuikina, M., Mae, A., and Pirhonen, M. 2004. Identification and characterization of Nip, necrosis-inducing virulence protein of Erwinia carotovora subsp. carotovora. Mol. Plant-Microbe Interact. 17:1366-1375.

Mondego, J. M. C., Carazzolle, M. F., Costa, G. G. L., Formighieri, E. F. Parizzi, L. P., Rincones, J., Cotomacci, C., Carraro, D. M., Cunha, A. F., Carrer, H., Vidal, R. O., Estrela, R. C., Garcia, O., Thomazella, D. P. T., Oliveira, B. V. de, Pires, A. B. L., Rio, M. C. S., Araújo, M. R. R., Moraes, M. H. de, Castro, L. A. B., Gramacho, K. P., Gonçalves, M. S., Neto, J. P. M., Neto, A. G., Barbosa, L. V., Guiltinan, M. J., Bailey, B. A., Meinhardt, L. W., Cascardo, J. C. M., and Pereira, G. A. G. 2008. A genome survey of Moniliophthora perniciosa gives new insights into witches' broom disease of cacao. BMC Genomics 9:548.

Murashige, T., and Skoog, F. 1962. A revised medium for rapid growth and bioassays with tobacco tissue culture. Physiol. Plant. 15:473-497.

Nitsch, J. P. 1969. Experimental androgenesis in Nicotiana. Phytomorphology 19:389-404.

Oliver, R. P., and Ipcho, S. V. S. 2004. Arabidopsis pathology breathes new life into the necrotrophs-vs.-biotrophs classification of fungal pathogens. Mol. Plant Pathol. 4:347-352.

Pemberton, C. L., and Salmond, G. P. C. 2004. The Nep1-like proteins-a growing family of microbial elicitors of plant necrosis. Mol. Plant Pathol. 5:353-359.

Purdy, L. H., and Schmidt, R. A. 1996. Status of cacao witches' broom: Biology, epidemiology, and management. Annu. Rev. Phytopathol. 34:573-594.
Qutob, D., Kemmerling, B., Brunner, F., Kufner, I., Engelhardt, S., Gust, A. A., Luberacki, B., Seitz, U. H., Stahl, D., Rauhut, T., Glawischnig, E., Schween, G., Lacombe, B., Watanabe, N., Lam, E., Schlichting, R., Scheel, D., Nau, K., Dodt, G., Hubert, D., Gijzen, M., and Numberger, T. 2006. Phytotoxicity and innate immune responses induced by Nep1 like proteins. Plant Cell 18:3721-3744.

Rio, M. C. S., Oliveira, B. V., Thomazella, D. P., Fracassi da Silva, J. A., and Pereira, G. A. G. 2008. Production of calcium oxalate crystals by the basidiomycete Moniliophthora perniciosa, the causal agent of the witches' broom disease of cacao. Curr. Microbiol. 56:363-370.

Schouten, A., Van Baarlen, P., and Van Kan, J. 2008. Phytotoxic Nep1-like proteins from the necrotrophic fungus Botrytis cinerea associate with membranes and the nucleus of plant cells. New Phytol. 177:493-505.

Shetty, N. P., Jorgensen, H. J. L., Jensen, J. D., Collinge, D. B., and Shetty, H. S. 2008. Roles of reactive oxygen species in interactions between plants and pathogens. Eur. J. Plant Pathol. 121:267-280.

Staats, M., Van Baarlen, P., Schouten, A., and Van Kan, J. 2007. Functional analysis of NLP genes from Botrytis elliptica. Mol. Plant Pathol. 8:209-214.

Svedruzic, D., Jonsson, S., Toyota, C. G., Reinhardt, L. A., Ricagno, S., Lindqvist, Y., and Richards, N. G. J. 2005. The enzymes of oxalate metabolism: Unexpected structures and mechanisms. Arch. Biochem. Biophys. 433:176-192.

Thompson, C., Dunwell, J. M., Johnstone, C. E., Lay, V., Ray, J., Schmitt, M., Watson, H., and Nisbet, G. 1995. Degradation of oxalic acid by transgenic oilseed rape plants expressing oxalate oxidase. Euphytica 85:169-172.

Van Breusegem, F., and Dat, J. F. 2006. Reactive oxygen species in plant cell death. Plant Physiol. 141:384-390.

Van Kan, J. 2006. Licensed to kill: The lifestyle of a necrotrophic plant pathogen. Trends Plant Sci. 11:247-253.

Veit, S., Worle, J. M., Nurnberger, T., Koch, W., and Seitz, H. U. 2001. A novel protein elicitor (PaNie) from Pythium aphanidermatum induces multiple defence responses in carrot, Arabidopsis, and tobacco. Plant Physiol. 127:832-841.

Walz, A., Zingen-Sell, I., Theisen, S., and Kortekamp, A. 2008. Reactive oxygen intermediates and oxalic acid in the pathogenesis of the necrotrophic fungus Sclerotinia sclerotiorum. Eur. J. Plant Pathol. 120:317 330 . 